\title{
The Soviet Gas Pipeline Incident: Extension of Collective Security Responsibilities to Peacetime Commercial Trade
}

\author{
Patrick J. DeSouza $\dagger$
}

\section{Problem}

In 1982, the Soviet Union began construction of a 3,000-mile pipeline to supply natural gas to Western Europe. ${ }^{1}$ To accomplish this massive undertaking, the Soviet Union sought to obtain financial credit, equipment, and technology from the West. On December 29, 1981, while the natural gas pipeline was still under construction, President Reagan barred U.S. companies from supplying pipeline equipment to the Soviet Union. President Reagan's decision was motivated by a variety of policy considerations, the most salient of which was the need to respond to the declaration of martial law in Poland. On June 18, 1982, the President broadened the ban to include all pipeline equipment manufactured by Western firms under license from U.S. companies. These restrictions were criticized by both domestic and international elites on political, economic, and legal grounds. The dispute ended when an informal understanding was reached among the various members of the Atlantic Alliance. On November 13, 1982, President Reagan announced the lifting of the sanctions.

This dispute within the Atlantic Alliance raised questions among international elites about the nature and extent of Alliance members' peacetime responsibilities. The outcome of the incident seemed to affirm an emerging norm that politico-military responsibilities of alliance members could not be extended automatically to the peacetime trade of commercial goods. ${ }^{2}$

$\dagger \quad$ J.D. Candidate, Yale University; Ph.D. Candidate, Stanford University.

1. The Soviet pipeline, built in part with Western materials and financing, is now complete. On January 1, 1984, France received the first deliveries of natural gas from the Soviet pipeline. Chronology 1984, 63 FOREIGN AfF. 678 (1985) (America and the World 1984).

2. "Commercial goods" are defined here as those goods not having military application. There is, however, an intermediate category of goods, such as aircraft engines, that have both military and commercial applications. A central problem for security alliances is how to distinguish and categorize such goods. This study takes the position that pipeline equipment is inherently a commercial item that indirectly contributes to the development of Soviet military power through the enhancement of Soviet economic power. Since this link is indirect, as well as debatable, it is difficult to gauge the degree to which the commercial trade involved in the 


\section{A. Norm Specification}

Identification of an emerging norm is conditioned by many variables and must be studied as part of an ongoing social process in which decisions $^{3}$ shaping the norm are made. This constitutive process ${ }^{4}$ must be specified more closely in order to understand the impact of the pipeline incident on international legal norms. Central to the task of norm specification in this incident is an examination of the concepts of alliances 5 and "state management of trade."6

\section{B. The Management of Alliance Behavior}

In the post-World War II era, there has been a continuing tension between the degree of independence with which states wish to act and the requirements of alliance participation. The United Nations Charter created a state system intended to facilitate the participation of territorial entities in the international arena. Under Articles 1(2), 2(4), and 55, the purposes of the United Nations were identified as resting on the respect among nations for the principles of equal rights, self-determination, and the territorial integrity of states. ${ }^{7}$ Yet, while the United Nations Charter

pipeline incident contributes to Soviet military power. It seems clear, however, that inclusion of all forms of trade in the military category would mistakenly assume that every transaction with the Soviets contributes to their military position.

3. Law may be conceived as a function of decisions characterized by expectations of both authority and control that are communicated to target audiences. McDougal, Lasswell \& Reisman, The World Constitutive Process of Authoritative Decision, in INTERNATIONAL LAW EsSAys: A Supplement to INTERnational LaW In CONTEMPORARY Perspective 192 (M. McDougal \& W. Reisman eds. 1981) [hereinafter cited as INTERNATIONAL LAW ESSAYS].

4. Law is made within a constitutive process which involves the exercise of authoritative power to provide an institutional framework for decisions and to allocate indispensable functions and values. The particular decisions emerging from this process, which are termed "public order" decisions, may be specialized to the shaping and sharing of particular values, such as wealth. Id. at 191-192.

5. By alliance is meant a group of states, linked either formally through legal codification or informally through common policies, which has as its basis a perceived commonality of interests. Alliances have been distinguished according to their nature and relationship, distribution of benefits and power, coverage in relation to the total interests of the nations concerned, coverage in time, and effectiveness of common policies and actions. H. MORGANthau, Politics Among Natrons 177 (4th ed. 1967). This incident is concerned with the interaction among the members of the Atlantic Alliance, best known by their military appellation, the North Atlantic Treaty Organization (NATO).

6. "State management of trade" refers to the ability of individual states to control their international transactions with other states. As one of the leading works in the field of international political economy notes: "[T] he nation-state has reaffirmed its power to shape strategies of foreign economic policy." Katzenstein, Introduction: Domestic and International Forces and Strategies of Foreign Economic Policy, in BETWEEN Power AND PleNTY 4 (P. Katzenstein ed. 1978).

7. Articles 1(2), 2(4), and 55 articulate clearly the goals of a system of public order established in the aftermath of World War II. U.N. CHARTER art. 1, para. 2: "To develop friendly relations among nations based on respect for the principle of equal rights and self-determination of peoples . . .;" Art. 2, para. 4: "All Members shall refrain in their international rela- 
has promoted state participation in the international system, it also has sanctioned the formation of defensive alliances, ostensibly to protect the integrity of the state system. ${ }^{8}$ Although Article 51, which embodies this principle of "collective security," was drafted to cover collective responses to actual attack, the strategic problems of the nuclear age have blurred the distinction between time of war and time of peace, and have required the formation of peacetime alliances to deter threats both to the security of states and to the state system. 9 The practical effect of the advent of peacetime alliances in the framework of a state system marked by conflict has been to limit independent state participation in the international system.

Alliances have limited the autonomy of national elites in the international process in at least two ways. First, within an alliance there always exist categories of alliance responsibility (e.g., political, military, economic) which are variable in scope and which are subject to extraterritorial management among the members. ${ }^{10}$ Second, alliances sometimes have imposed limits upon the political independence of member states, or of those states outside the alliance that represent strategic interests important to the alliance. Spheres of influence are set up to communicate to adversaries the intent of the alliance to exclude outside influences and to shape political decisions. Such exclusionary communications have been conceptualized as "critical defense zones" and articulated by alliances in such policies as the Monroe Doctrine, the Brezhnev Doctrine, and the Carter Doctrine with its Reagan Codicil. ${ }^{11}$ The limitation of

tions from the threat or use of force against the territorial integrity or political independence of any state, or in any manner inconsistent with the Purposes of the United Nations;" Art. 55: "With a view to the creation of conditions of stability and well being which are necessary for peaceful and friendly relations among nations based on respect for the principle of equal rights and self-determination of peoples. . ..."

8. U.N. ChARTER art. 51: "Nothing in the present Charter shall impair the inherent right of individual or collective self-defense if an armed attack occurs against a Member of the United Nations ...."

9. States that possess nuclear weapons and modern delivery systems may be able to exert political influence over other states, especially those without nuclear weapons, within a particularly compressed time horizon. The ability of nuclear powers to use their influence to bring about political results has been popularly referred to as "nuclear blackmail." Blackmail with respect to foreign policy decisionmaking has been conceptualized in terms of "strategic" moves in a dynamic process of communication and enforcement between states. See T. ScHElling, THE STRATEGY OF CONFLICT 119-161 (1963).

10. These categories of responsibility sometimes result from mutual agreement and at other times are the product of the stronger members' imposition of their policy preferences on the weaker. Note, Extraterritorial Application of the Export Administration Act of 1979 under International and American Law, 81 Mich. L. REv. 1308, 1330 (1983).

11. For an elaboration of the concept of "critical defense zones" and related notions, see Reisman, Critical Defense Zones and International Law: The Reagan Codicil, 76 AM. J. INT'L L. 589 (1982). For an examination of the Brezhnev Doctrine, see N. Rostow, Law and the Use of Force by States: The Brezhnev Doctrine, 7 YALE J. WorLd PUB. ORder 209 (1981). See 
political autonomy through such policies has exacerbated the tension, basic to alliance management, between the need for members to cooperate for collective aims and their desire to pursue independent policies.

Alliance policies have often focused efforts on withholding power economic, military, and diplomatic - from their adversaries. In order for an alliance to be effective in carrying out such policies, it must have at its foundation a high degree of shared interests. This cannot always be presumed to exist among the members of peacetime alliances, which tend to confine their concerns to a fraction of the total interests and objectives of their members. ${ }^{12}$

Under a traditional "realist" analysis, ${ }^{13}$ an insufficiency of shared interests within an alliance can only be overcome by having strong leadership by a powerful state. ${ }^{14}$ An oft-quoted remark of Thucydides captures the essence of this view: "The strong do what they have the power to do and the weak accept what they have to accept."15 In the pipeline incident, under a traditional, realist view of alliance behavior, the United States might have been expected to use its political and military leverage over its allies to enforce trade sanctions. This use of leverage would have prevented the transfer of economic power in the form of credit and pipeline equipment to the Soviet Union and its allies. The inability of the United States to enforce the sanctions suggests that political and military dominance does not give to the leader of an alliance the power to regulate commercial trade between the members of the alliance and their political adversaries. ${ }^{16}$

\section{State Management of Trade}

Some analysts have concluded that attempts by the United States to wield economic power through trade restrictions have had limited suc-

generally M. McDougal \& W. Reisman, International Law in Contemporary PerSPECTIVE 175-186 (1981).

12. H. MoRganthau, supra note 5, at 179. During peacetime, the common interest in unity against a "threat" is weakened, making coordinated policies more difficult to achieve.

13. Id. at 13-14.

14. R. Keohane \& J. NYE, Power AND INTERDEPENDENCE 44 (1977). For a general treatment of the problem of leadership in a world of fragmented interests, see Rosenau \& Holsti, United States Leadership in a Shrinking World, 35 WORLD PoL. 368, 373 (1983).

15. ThuCYdides, The PeIOPENNESIAN WAR 402 (R. Warner trans. rev. ed. 1972).

16. Contemporary international relations theory has come to distinguish the effective uses of power by states according to issue areas such as trade, finance, military, and ideology. Such a mode of analysis is known as "issue structuralism." Its basic premise is that power resources in one issue area do not predict effective power across issue areas. R. KEOHANE \& J. NYE, supra note 14, at 50. 
cess in the post-war period. ${ }^{17}$ Efforts by the United States to get its allies to act in concert for the purpose of denying political adversaries economic power have met with even less success. In fact, attempts to restrict economic activity with such adversaries as the Soviet Union have often resulted in heavy costs, including foregone gains from trade, intraalliance friction, increased solidarity within the opposing alliance, increased Soviet self-sufficiency, albeit at a higher cost, and the growth of bureaucracy as Atlantic Alliance members have tried to develop procedures and controls for implementing the restrictions. ${ }^{18}$

A historical analysis of United States attempts to persuade the Atlantic Alliance to restrict its trade with the Soviet Union reveals heightened levels of strain within the Alliance. European members have shown increasing reluctance to accept limitations on their authority to manage their own trade relations.

The development of the Atlantic Alliance relaticnship in the economic issue area may be organized into three phases. ${ }^{19}$ During the first phase (1948-68), U.S. policy-makers consistently took the position that the commercial benefits the West might derive from trade with the Soviets would be offset by the consequent strengthening of the Soviet military. ${ }^{20}$ Yet, the restrictive trade policies unilaterally formulated by the United States received only grudging support from the European countries whose economies 'were recovering from war and adjusting to peacetime conditions.

The United States sought to achieve compliance, in part, through legislation. The Export Control Act of 1949,21 Section 117(d) of the Marshall Plan, ${ }^{22}$ the Mutual Defense Assistance Control Act of 1951,23 and

17. For a broad treatment of the uses of economic power in the post-World War II era, see K. KNORR, POWER OF NATIONS 134-165 (1975).

18. Id. at 145 .

19. For a more detailed treatment which divides the period into four phases, see J. Braathu, Unilateralism and Alliance Cohesion: The United States, Western Europe, and the Regulation of Energy-Related Trade with the Soviet Union, 18 COOPERATION AND CONFLICT 21, 27-38 (1983).

20. Id. at 26.

21. The Export Control Act of 1949 authorized the President to impose sanctions against those countries contravening United States export regulations regarding the communist bloc. Export Control Act of 1949, Pub. L. No. 81-11, 63 Stat. 7 (current version at 50 U.S.C. app. $\S 2401$ (1979)).

22. Section 117(d) of the Marshall Plan provided for the suspension of aid to any country supplying goods embargoed by the United States to communist countries. Economic Cooperation Act of 1948, Pub. L. No. 80-472, 62 Stat. 137 (22 U.S.C. $\$ \S 1501-1523$ (repealed 1951 and 1954)).

23. The Mutual Defense Assistance Control Act of 1951, commonly known as the Battle Act, expanded American trade controls and authorized the President to cut off all military, economic, and financial aid to countries that exported embargoed products to any nations 
the 1962 Congressional amendments to the Export Control Act of $1949,{ }^{24}$ were all efforts to extend U.S. law to the European allies in order to obtain compliance with U.S. trade policies. Intergovernmental efforts to obtain compliance focused on a coordinating committee (CoCom), set up during 1949-50 to regulate and coordinate Alliance trade with the Eastern bloc countries. ${ }^{25}$ The creation of CoCom did not resolve the issue of the degree to which economic decisionmaking had to be shared in order to achieve mutual security. Because CoCom can act only with the unanimous agreement of its members, the problem for the United States over time has been to get the rest of the Alliance not only to agree on controls but also to implement them accordingly. In this early period, such attempts were difficult; as time went by, agreement became impossible, especially with respect to goods that had purely commercial uses.

A key test in this early period came in 1962, in response to Soviet attempts to construct the Druzhba oil pipeline to Eastern Europe. ${ }^{26}$ The oil pipeline offered the prospect of increased oil supplies to the West and, more immediately, of increased employment in West Germany and other Western European countries receiving orders for steel pipe. The United States attempted to block the transaction through CoCom and, when this failed, tried to gain leverage over its allies by obtaining an informal NATO resolution opposing the sale. Notwithstanding these efforts, the

"threatening the security of the United States." Pub. L. No. 82-213, 63 Stat. 479 (1961) (current version at 22 U.S.C. $\$ \S 1611-1613 d(1970)$ ).

24. The 1962 amendments to the Export Control Act of 1949 granted the President discretionary power to deny trade licenses if the products in question were deemed to make a "significant contribution to the military or economic potential of the adversary." Pub. L. No. 87-515, 76 Stat. 127, $\S 4$ (1962) (codified at 50 U.S.C. app. $\$ \S 2021-2023,2025 \& 2032$ (1976)).

25. The Coordinating Committee for Multilateral Security Export Controls (CoCom) includes Japan and all NATO countries except Iceland. CoCom is a forum in which trade decisions are examined. CoCom was created by informal agreement among its members and works on the principle of unanimous agreement. CoCom has three major functions: 1) to establish and update lists of embargoed products and technologies; 2) to act as a clearinghouse for requests submitted by members for shipping goods to proscribed countries; and 3) to coordinate administration and enforcement activity among member nations. See Buckley, Control of Technology Transfers to the Soviet Union, DEP'T ST. BuLl., Aug. 1982, at 71, 72. There are essentially three categories of controls: a) munitions, b) atomic energy, and c) industrial commercial. There are also three levels of control: a) total embargo, b) quantitative limits, and c) surveillance. See Braathu, supra note 19 , at $40 \mathrm{n}$. 13. It is important to remember that CoCom has no formal treaty or charter and is not officially part of any organization. See $3 \mathrm{~A}$. Lowenfeld, Trade Controls for Political Ends 11-12 (1977). CoCom functioned, in the past, because of a shared perception of threat from the Soviet Union and its allies. However, as:

1) European countries became less dependent on aid; 2) technological superiority of the United States both vis-à-vis Western Europe and vis-à-vis the East narrowed; and 3) perceptions of the communist threat declined faster in Europe and Japan than in the United States, Cocom and the multilateral denial effort in general became less effective and more subject to disagreements. Id. at 13.

26. Braathu, supra note 19, at 29. See also Mufson, United States Effort to Block Soviet Gas Pipeline Recalls Failed Embargo of Twenty Years Ago, Wall St. J., July 14, 1982, at 32, col. 1. 
British, Italians, Swedes, and Japanese fulfilled their contracts. Although the West Germans eventually yielded to United States pressure, their compliance came at the expense of a parliamentary crisis. ${ }^{27}$

The second period (1969-1974) was marked by a reversal of the U.S. policy of trade denial. As part of its strategy of detente, the U.S. tried to use trade incentives to influence Soviet foreign policy. The Export Administration Act of $1969^{28}$ narrowed the definition of national security under which the restrictions had been justified. ${ }^{29}$ In addition, it removed references to the "economic potential" that American trade would presumably bestow on the Soviet Union. ${ }^{30}$

The interlude provided by detente allowed the West Europeans to expand their economic ties with the Soviet Union and its allies. Increasing Soviet supply of energy to Western Europe raised the possibility of a link between Europe's energy security and the continuation of nonconfrontational policies toward the Soviet Union. While there remained categories of trade that were subject to restriction, such as nuclear or military technology, independence of action in the commercial area was expanded.

The third phase (1975-present) saw renewed restrictions on United States exports to the Soviet Union. With the Jackson-Vanik amendment to the Trade Reform Bill of $1973^{31}$ and the Stevenson Amendment to the Export-Import Bank Act of December, 1974, ${ }^{32}$ Congress tied economic exchange to Soviet domestic policies. The United States by this time had come to question the policy of detente, and had returned to a strategy of trade denial to further the policy goals of the Atlantic Alliance. ${ }^{33}$

27. Mufson, supra note 26.

28. Export Administration Act of 1969, Pub. L. No. 91-184, 83 Stat. 841 (current version at 50 U.S.C. app. $\$ 2401$ (1979)).

29. Id. at $\S \S 3-4$. The concept and scope of national security has expanded over time. See Export Administration Act of 1979, $\S ~ 2,3 \&$ 5, Pub. L. No. 96-72, 93 Stat. 503 (50 U.S.C. app. §§ 2401-2420 (Supp. III 1979)).

30. Congress limited its findings regarding the adverse impact of unrestricted trade on national security to trade making a contribution to the military potential of other nations. See supra note 28 , at $\S 2(2)$.

31. After eighteen months of executive-congressional debate starting in 1973, Senator Jackson, in October 1974, announced a compromise, under which Soviet and Eastern European trade benefits would be made conditional upon a relaxation of Soviet and Eastern European emigration policies. J. Spero, The Polrtics of INTERnational Economic Relations 317 (2d ed. 1981); Trade Act of 1974, Pub. L. No. 93-618, 88 Stat. 1978 (19 U.S.C. § 2431 (1982)); see also 119 Cong. Rec. 11,549 (1973).

32. The Stevenson Amendment to the Export-Import Bank Act killed both the "North Star" and Yakutsk gas projects, which were crucial to American-Soviet energy cooperation, by imposing severe credit limitations. See Braathu, supra note 19, at 33.

33. In response to the Afghanistan invasion, the United States tried without success to obtain the support of its European allies for trade control measures. See Braathu, supra note 19, at 37. For a general analysis of the failures of detente, see Breslauer, Why Detente Failed: An Interpretation, in MaNAGing United States-Soviet RIVAlRY 319 (A. George ed. 1983). 
This return to a strategy of trade denial was largely the result of the failure of the Carter Administration to influence Soviet foreign policy through diplomatic or military channels. In July 1978, the Carter Administration retaliated against Soviet treatment of dissidents and American journalists by limiting computer sales and oil drilling equipment to the Soviet Union. ${ }^{34}$ In December 1979, the administration tried broadly to restrict exports to the Soviet Union, including grain and advanced technology, in retaliation for the Soviet invasion of Afghanistan. ${ }^{35}$ These economic measures only served to bring to the surface differences between the U.S. and its allies over cooperation in denying trade to the Soviets. In fact, after both Carter Administration decisions, the Soviets were able to fill their needs by trade with other capitalist countries. ${ }^{36}$

\section{Facts}

The construction of the 3,000 mile pipeline to bring natural gas from the Urengoi fields in Siberia to the West European gas network is an important part of Soviet political and energy planning. The Soviets plan eventually to export 40 billion cubic meters of natural gas annually to Western Europe, tripling their current export level. ${ }^{37}$ Since 1978, when the Soviets first proposed the construction of a natural gas pipeline from Siberia, ${ }^{38}$ it was apparent that pipe and equipment from Western Europe and Japan and credit from Western banks would be essential if the pipeline were to be completed on time. ${ }^{39}$

On June 24, 1981, members of Congress, led by Senator Jake Garn (RUtah), sent a letter to President Reagan expressing concern that the pipeline would endanger Western security and suggesting alternatives to West European participation in the pipeline. ${ }^{40}$ The legislators feared that Western Europe could become susceptible to blackmail if it relied on the Soviet Union for a substantial portion of its supply of natural gas. In July, when a consortium of German banks, led by Deutsche Bank and

34. Spero, supra note 31 , at 319 .

35. Id. at $319-20$.

36. Id. at 320 .

37. J. HaRdT \& D. Gold, Soviet Gas Pipeline: United States Options 1 (Cong. Research Service Issue Brief 82020,1982 ) (on file with the Yale Journal of International Law).

38. The Urengoi field on the Tal Peninsula in western Siberia is the largest gas field in the world, and will add the equivalent of four million barrels of oil per day to Soviet gas production. Stern, Specters and Pipe Dreams, ForeIGN PoL'y, Fall 1982, at 21-22.

39. Soviet motives in seeking Western technology and financing are discussed in Loeber and Friedland, Soviet Imports of Industrial Installations Under Compensation Agreements: West Europe's Siberia Pipeline Revisited, Colum. J. WorLd Bus., Winter 1983, at 51, 57.

40. This fact and others in this section were derived from a chronology set forth in $\mathrm{J}$. HARDT \& D. GOLD, supra note 37, at 12-20. 
the AKA Ausfuhrkredit GMbH, agreed to provide some 3.4 billion DM in credits for the compressor stations, President Reagan tried unsuccessfully at the Ottawa Economic Summit (July 19-21) to persuade the West European leaders to abandon their support of the Soviet pipeline. ${ }^{41}$ By the end of 1981, Western European countries had become deeply involved in the project, to the frustration of the U.S. administration.

In September 1981, Nuovo Pignone of Italy agreed to supply nineteen compressor stations for the pipeline. ${ }^{42}$ Also in September, the Soviet equipment trading agency signed an agreement with Mannesman (FRG) and Creusot-Loire (France) to supply twenty-two compressor stations for the pipeline. ${ }^{43}$ In November, the Soviet Union and Ruhrgas A.G. (FRG) signed an agreement on the price and quantity of natural gas to be delivered by the pipeline until the year 2006.44 Of greater concern to the United States was French approval, on December 10, of the sale by Thomas-CSF of electronic systems for controlling the flow of gas in the pipeline. Analysts in the United States government felt that this was a particularly dangerous sale because it included computer technology that might be used by the Soviets to further their military development.45 Europeans, who by this point had become accustomed to making their own decisions about trade with the Eastern bloc, did not share the U.S. attitude. The lack of consensus on this issue foreshadowed the tensions which the 1982 pipeline incident would bring about.

The imposition of martial law in Poland on December 29 served as the catalyst that forced a showdown over the issue of collective trade policy among the members of the Atlantic Alliance. President Reagan declared that the Soviets bore heavy responsibility for the imposition of martial law and announced a series of sanctions against the Soviet Union that included the suspension of exports of oil and gas equipment and other high technology equipment to the Soviets. ${ }^{46}$ These sanctions stripped away the image of alliance "neutrality" and had an immediate impact, not only on the Soviets, but also on West European countries, many of whose contractors used U.S. licensed technology in completing their contracts with the Soviet Union.

On January 8, 1982, the General Electric Company announced that its

41. See J. HARDT \& D. Gold, supra note 37, at 20.

42. Id. at 19.

43. Id.

44. Id.

45. Interviews, U.S. Department of State officials, July 1984 [on file with the Yale Journal of International Law].

46. Id. at 18-19. See also Joffe, Europe and America: The Politics of Resentment (cont'd) 61 FoReIGN AFF. 569, 571 (1983) (America and the World 1982). 
application for a license to export $\$ 175$ million worth of rotors and other components for compressor stations had been denied by the Commerce Department. The company was a subcontractor for John Brown (England), Nuovo Pignone (Italy) and AEG-Telefunken (FRG) which had agreed to supply compressor stations to the Soviets. ${ }^{47}$ European reaction to the implementation of United States policy was swift. On January 13, 1982, West German Economic Minister Otto von Lambsdorff told the Cabinet that the Government's pledge not to undermine United States sanctions only applied to new contracts and those contracts for which a United States firm was the prime contractor. ${ }^{48}$ This distinction appeared to exclude the German compressor contracts for which General Electric was a subcontractor. On the same day, Gaz de France signed a twentyfive year agreement with the Soviets to purchase gas from the pipeline beginning in 1986. This agreement was followed by a second one on February 10, by a group of French banks, granting a credit of $\$ 140$ million to the Soviets to finance purchases of equipment for the pipeline from French companies. ${ }^{49}$ On January 29, Italy's state energy agency announced that it had completed a similar agreement on the price and quantity of Soviet gas to be delivered. ${ }^{50}$ On February 2, the Japanese Export-Import Bank announced that Komatsu would be allowed to complete its sale of pipe-laying equipment to the Soviet Union. ${ }^{51}$ The machines were similar to an embargoed pipelayer made by Caterpillar in the United States. Thus, it seemed as if the United States response to the imposition of martial law in Poland would be accompanied by undiminished economic contacts and cooperative ventures between the U.S. allies and the Soviets. It was as if a general had charged into battle without the troops.

The Reagan Administration tried, without success, to convince its allies that "commercial prudence with the Soviets was needed for maintenance of their security interests." 52 U.S. frustration over the allies' refusal to commit themselves to a policy of trade sanctions peaked on June 6, during the Versailles Economic Summit, when the most that the alliance could agree to was a communique indicating their good intentions. $^{.33}$

Having failed to secure voluntary cooperation, the Reagan Adminis-

47. J. HARDT \& D. Gold, supra note 37 , at 18.

48. Id.

49. Id. at 17-18.

50. Id. at 18 .

51. Id.

52. Joffe, supra note 46 , at 574 .

53. Id. 
tration turned to more coercive measures to achieve a "coordinated" policy. On June 18, President Reagan extended the embargo to encompass not only American pipeline suppliers, but also their subsidiaries and licensees in France, Germany, England, and Italy. Unlike the denial of export licenses to U.S. suppliers, this action had a real chance of damaging the gas pipeline by closing off the last conduit for those crucial components embodying superior American turbine technology. ${ }^{54}$

The expanded embargo only generated increased European resistance. On June 22, foreign ministers of the European Economic Community (EEC) countries issued a statement asserting that the extended ban on oil and gas equipment violated international law in attempting to impose American jurisdiction over European contracts. On July 22, the French government officially ordered those companies involved in the pipeline deal to honor their contracts despite U.S. actions. ${ }^{55}$ On July 24, the Italian Foreign Ministry publicly stated that Italian contracts with the Soviet Union would be honored. ${ }^{56}$ On August 3, in accordance with the provisions of the 1980 Protection of Trading Interests Act, ${ }^{57}$ Lord Cockfield, the British Trade Secretary, ordered four companies producing equipment in Britain under U.S. license - American Air Filter, Baker Oil Tools, Smith International, and John Brown Engineering - to honor their contracts with the U.S.S.R. ${ }^{58}$ Finally, on August 12, the EEC issued a formal protest in response to President Reagan's expansion of the ban on pipeline equipment. 59

By the end of August, members of the Reagan Administration were beginning to realize that the continuing confrontation was counterproductive. On August 31, senior advisors recommended to President Reagan that he look for ways to compromise with those European companies violating his pipeline embargo. On September 9, the administration imposed limited sanctions against the British company John Brown after it shipped six turbines to the U.S.S.R. ${ }^{60}$ On October 5, the United States imposed limited sanctions against four West German companies. ${ }^{61}$ Finally on November 13, after almost a year of conflict, the Reagan

54. Id.

55. J. HARDT \& D. GolD, supra note 37 , at 16.

56. Id.

57. Protection of Trading Interests Act, 1980, ch. 11.

58. J. HARDT \& D. GolD, supra note 37 , at 15.

59. Id.

60. U.S. courts deferred to the authority of the political branches during the pipeline dispute. See Dresser Industries Inc. \& Dresser (France) S.A. v. Baldridge, 549 F.Supp. 108, 110 (D.D.C. 1982) (denying injunctive relief to companies penalized for violation of the Reagan Administration pipeline ban).

61. J. HARDT \& D. GoLD, supra note 37 , at 13. 
Administration lifted the sanctions altogether. ${ }^{62}$

\section{Conflicting Claims}

The U.S. and its allies had different perspectives on the strategy of trade denial. The arguments each side offered often reflected narrow conceptions of self-interest rather than any principled basis for alliance policy. In addition, each side engaged in selective distortions of reality and manipulations of "hard" data in order to further its interpretation.

\section{A. United States Claims}

The Reagan Administration offered three principal arguments against West European participation in the pipeline project. ${ }^{63}$ These were given varying emphasis at different points in the dispute. Initially, the American case stressed the danger of increasing energy dependence on a powerful opponent. ${ }^{64}$ The United States argued that dependence on Soviet natural gas (at least thirty percent of West European natural gas needs) and equipment orders (between ten and fifteen billion dollars over the next five years) would make West European participants vulnerable to Soviet threats to cut off supplies or terminate orders in a crisis. ${ }^{65}$ Analysts cited Yugoslavia (1948), Israel (1956), Albania (1961), and China (1962) as instances in which the Soviets had interrupted energy exports to achieve political gains. ${ }^{66}$ After the imposition of martial law in Poland in December 1981, the Reagan Administration couched its arguments for sanctions in terms of political morality. The United States asserted that failure to support sanctions implied consent for the suppression of the Polish trade union, Solidarity. ${ }^{67}$ Finally, the United States argued that the transfer of Western technology, subsidized credit, and hard currency would aid the Soviet military buildup, making the task of maintaining Atlantic security much harder. ${ }^{68}$ Arguing against this "contribution" to Soviet power, the United States tried to distinguish the pipeline situation from its October 15, 1982 decision to sell grain to the Soviet Union. The Reagan Administration argued that European gas purchases would contribute vital resources to the Soviet economy, while U.S. grain sales had extracted billions of dollars in cash which would have been used to sup-

62. Id. at 12 .

63. Joffe, supra note 46 , at 574 .

64. Id.

65. Id. at 570 (U.S. perspective on West European energy dependence). See J. HARDT \&

D. GoLD, supra note 37, at 1 (U.S. estimate of value of equipment orders).

66. Joffe, supra note 46 , at $570 \mathrm{n} .1$.

67. Id. at 571 .

68. Id. 
port a further Soviet military buildup. ${ }^{69}$

The administration's arguments not only inspired sharp criticism from abroad, but divided the United States foreign policy community. Two schools of thought could be identified. ${ }^{70}$ One group, led by Secretary of Defense Weinberger and Senator Garn, stressed that Europe would become hostage to the Soviet Union if the deals were completed, and that the transactions would be beneficial to the Soviet military. ${ }^{71}$ The other group, represented by Richard Lesher and Donald Campbell of the United States Chamber of Commerce, argued that United States pressure could not stop the pipeline from being built, ${ }^{72}$ and could only undermine the alliance. The Weinberger group eventually forced this school to yield to its concerns about the possible "Finlandization" of Western Europe. ${ }^{73}$

\section{B. European Claims}

The West European allies generally supported increased imports of natural gas and oil from the Soviet Union as well as increased sales of energy equipment on competitive credit terms. Three reasons predominated. First, it was argued that any addition of energy to the world market would help hold down prices. ${ }^{74}$ Energy security is perceived differently in the United States than in Western Europe and Japan. In the latter countries, where energy independence is not possible, decisionmaking elites see energy security as a product of diversification of supply. Analysts questioned how much coal the United States could export to Western Europe in an emergency, and how much coal the West Europeans could substitute for gas, given their existing energy infrastructure. ${ }^{75}$ Second, it was argued that large equipment orders would be beneficial to stagnant European and Japanese metallurgy and machinery sectors, providing certain employment and production prospects for

69. Id. at 572 .

70. J. HARDT \& D. Gold, supra note 37, at 3-4.

71. Members of the "Weinberger" group searched for ways to delay, if not to stop, the pipeline. Some recommendations included: a) all-out legal and political efforts to use the leverage conferred by the General Electric patents on the pipeline technology; b) an offer of United States coal to replace all or part of the additional deliveries of Soviet gas from the pipeline; and c) tying human rights requirements to equipment sales for the pipeline with a requirement of proof that "forced labor" was not being used in the construction of the pipeline. Id. at 3.

72. Members of the "Lesher" group favored the development of additional coal exports that might serve as a "safety net" against threats of political pressure by the Soviet Union. Id. at 5 .

73. "Finlandization" refers to that process or state of affairs in which, under the cloak of maintaining friendly relations with the Soviet Union, the sovereignty of a country becomes reduced. Laqueur, Europe: The Specter of Finlandization, CoMmENTARY, Dec. 1977, at 37.

74. J. HARDT \& D. GOLD, supra note 37 , at 3.

75. Id. at 5 . 
many years to come. ${ }^{76}$ Finally, it was asserted that economic interdependence with the East would stabilize political relations and provide room for Western Europe to maneuver in a crisis. ${ }^{77}$

Perceptions of each of the European allies about pipeline policy seemed to vary with the extent of its economic stake in the project.78 West Germany took the leading role in the pipeline trade, partly because of its experience of twenty years earlier in the Druzhba pipeline affair, and partly because of its large economic interest in the project. West Germany is expected to buy about 30\% of the gas and has the largest contracts to provide equipment of any ally. Each year for twenty-five years, beginning in 1986, it will import 370 billion cubic feet of natural gas. Equipment supply contracts for West German companies total about $\$ 1$ billion and promise at least 1,000 new jobs. ${ }^{79}$ With so much at stake, it is no wonder that the Frankfurter Rundschau, on November 19, 1982, called the American sanctions policy "the biggest flop of the year." 80

France supported the pipeline project by lending money directly to the Soviet Union. A consortium of three banks, led by Credit Lyonnais, offered $\$ 850$ million of credits at $7.8 \%$ interest to cover $85 \%$ of the cost of pipeline equipment to be purchased in France. The loan would be repayable over ten years and would be insured by a quasi-public agency under the supervision of the French government. ${ }^{81}$ Gaz de France, a government-owned company, agreed to buy 280 billion cubic feet of natural gas a year from the pipeline over the next twenty-five years. This would double the current level of French gas purchases from the Soviet Union. ${ }^{82}$ Not surprisingly, Le Monde joined the German press in its condemnation of the American sanctions, asserting that the embargo had done more damage to the cohesion of the Atlantic Alliance; which President Reagan had wanted to strengthen, than to the Soviet Union which President Reagan had wanted to punish. ${ }^{83}$

Britain had pipeline contracts valued at about $\$ 383$ million, spread among a dozen firms. Of that amount, $\$ 228$ million worth of contracts

76. Id. at 3.

77. There is at least one economic model that indicates a negative relationship between conflict and trade. See Polachek, Conflict and Trade, 24 J. Conflict REsolution 55 (1980).

78. Mufson, United States is in a Sharp Fight With European Allies, Wall St. J., Aug. 31, 1982, at 29, col. 1 (detailing the economic stakes involved for each of the allies).

79. Id. at col. 2.

80. Joffe, supra note 46 , at 575 .

81. Mufson, supra note 78, at col. 3.

82. Id.

83. Joffe, supra note 46 , at $574-75$. 
were affected by the United States regulations. ${ }^{84}$

Italy was also heavily committed to the pipeline project. It agreed to buy about 280 million cubic feet of natural gas a year for twenty years at a price of $\$ 4$ per thousand cubic feet. This contract gave the Italians the best price of any member of the alliance. Credit granted by Italy covered as much as $85 \%$ of the roughly $\$ 1$ billion in contracts granted by the Soviets to Italian companies. ${ }^{85}$ The Italians instructed their companies to fulfill their contracts, but "sincerely" sought "frank and fair discussions" 86 between Washington and the European community over the dispute.

The dispute over pipeline policy offers an example of the problems of perception and misperception in international relations. ${ }^{87}$ The European allies could argue that 5-6\% dependence on Soviet energy exports (including gas, oil, and uranium) would not possibly lead to European vulnerability in times of political crisis. The United States, on the other hand, could offer the picture of $30 \%$ dependence on Soviet natural gas (excluding other energy sources) as the more accurate indicator of European vulnerability. ${ }^{88}$ The Europeans continually claimed that the U.S. position was inconsistent. ${ }^{89}$ They questioned whether the link between American sanctions and martial law in Poland, if successful in pressuring the Poles to lift martial law, would also eliminate European dependence and dampen Soviet military capabilities. They also doubted whether assistance to their domestic steel industries in obtaining pipeline equipment sales was any different from President Reagan's appeasement of midwestern grain farmers in the United States with their problems of overproduction and falling prices. These European doubts received additional support from a study by Wharton Econometrics ${ }^{90}$ based on the principles of comparative economic advantage, which showed that the Soviet Union, a lackluster grain producer, was better off buying grain abroad and devoting saved resources to energy production. With resources saved from the import of grain, the Soviets could develop more energy supplies. These, in turn, could be sold to Europe, producing profits that might be used either to buy more American grain or to increase military spending.

84. Mufson, supra note 78 , at col. 4 .

85. Id.

86. Painton, Imbroglio Over a Pipeline, Time, Aug. 2, 1982, at 30.

87. See generally R. JeRvis, Perception AND Misperception IN INTERNATIONAL ReLATIONS (1976).

88. Joffe, supra note 46 , at 570 .

89. Id. at 571.

90. Wharton Econometric Forecasting Associates, Comparative AdVANTAGe IN Soviet Grain and ENERgY Trade (1982). See also Joffe, supra note 46, at 572. 


\section{Conflicting Conceptions of Lawfulness}

Both the United States and the European allies developed legal arguments to reinforce and legitimize their respective policy claims. These arguments illustrated the differing perspectives of the two sides on the nature of the collective security system to which they belonged.

\section{A. U.S. Claims}

U.S. legal claims were developed along three lines. First, the Reagan Administration placed the controls in the context of U.S. foreign policy and the international obligations of the alliance. Second, the administration argued that the European allies had accepted the risk of U.S. export controls in contracting for the use of U.S. technology and equipment. Third, the U.S. claimed that "reasonable" extraterritorial extensions of jurisdiction were permissible under international law, and that, given the shared policy of alliance security, U.S. export controls were "reasonable."

With respect to the first claim, the United States crafted a broadly conceived argument based on its reading of an "agreement" by the Alliance. On June 6, 1982, two weeks before the extension of export controls to the European allies, the leaders of the Western Alliance held a summit meeting at Versailles. Despite "some disagreement," the U.S. expressed satisfaction over the degree to which the allies had managed to agree on a common approach to the management of East-West economic relations. In the American view, the summit countries had agreed to "pursue a prudent and diversified economic approach with respect to the USSR and Eastern Europe, consistent with U.S. political and security interests."91 One reason for this expansive view of what had been accomplished at Versailles may have been the pledge to improve consultative mechanisms within CoCom in order both to exercise stricter control over exports of strategic goods to Warsaw Pact countries and to coordinate national arrangements for the enforcement of security controls. ${ }^{92}$ Given U.S. preoccupation with East-West security considerations, ${ }^{93}$ and an al-

91. Meissner, United States Approach to East-West Economic Relations, DEP'T ST. BuLl., Sept. 1982, at 30. Cf. Joffe, supra note 46, at 574 (describing differing interpretations of the Versailles summit).

92. Meissner, supra note 91 , at 30 .

93. Id. at 31. The United States made three principal arguments in support of its broad conception of the "security" threat. First, the United States believed that because of the "heavy responsibility" that the Soviet Union bore for the imposition of martial law in Poland, it could not be rewarded by business as usual in foreign economic relations. Id. Second, Soviet "intimidation" served to underline the danger that the European allies would be jeopardizing their security by becoming dependent on Soviet energy supplies. Joffe, supra, note 46, at 571 . Finally, the United States asserted that Soviet ability to affect political outcomes in other 
ready inflated view of what was achieved at the summit, the United States may have read into this pledge a solid commitment to the use of sanctions. The U.S. did acknowledge that East-West trade plays a greater role in the economies of the European allies than in that of the United States, but nevertheless considered the value of a common sanctions policy to outweigh the economic costs to each state. ${ }^{94}$

The second U.S. claim was that the European allies had assumed the risk of sanctions by agreeing to clauses in trade contracts stipulating that the licensee or purchaser would abide by U.S. regulations in selling U.S. technology or products incorporating U.S. technology to third countries. ${ }^{95}$ Since these clauses had been in use since the $1950 \mathrm{~s},{ }^{96}$ the U.S. could argue that the possibility of sanctions, no matter how unlikely, should have been factored into the assessment of business risk.

The third U.S. claim was that U.S. export control regulations could legitimately be extended to European subsidiaries of American corporations and to licensees of U.S. technology because they involved "reasonable" extensions of jurisdiction. ${ }^{97}$ In assessing the "reasonableness" of U.S. jurisdiction, the Legal Adviser to the Department of State attempted to balance U.S. perceptions of the collective interests of the alliance against allied perceptions of their respective national interests. ${ }^{98}$

states - Soviet power - should not be enhanced through trade with the West in such critical technology. Id. Benefits to the Soviets from "exploiting" the West's advanced technology included: a) saving billions of dollars by acquiring proven Western technology; b) saving years of research time; c) narrowing the technological gap with the West; d) avoiding time consuming errors; and e) knowing in advance that new systems will work properly and knowing where to look should a product falter. For an analysis of the advantages of CoCom controls in countering Soviet gains from exploiting Western advanced technology, see Mally, Technology Transfer Controls, DeP'T ST. Bull., Nov. 1982, at 52, 54.

94. Buckley, The Case for Sanctions Against the Soviet Union, DeP'T ST. Bull., Sept. 1982, at 37, 38. See also Dam, Extraterritoriality and Conflicts of Jurisdiction, DEP'T ST. Bull., June 1983, at 48, 52.

95. J. HardT, Soviet Gas Pipeline: U.S. Sanctions and Their Implications (Cong. Research Service Issue Paper O219S, 1982)(on file with the Yale Journal of International Law).

96. $I d$.

97. Robinson, Economic Regulation and International Jurisdictional Conflict, DEP'T ST. BuLL., Oct. 1982, at 37.

98. Id. The Legal Adviser's approach in developing a "rule of reasonableness" required weighing and balancing factors including, inter alia: a) links such as nationality, residence, or economic activity between the regulating state and the persons responsible for the activity taken; b) the importance of regulation to the regulating state; c) extent of the "other" states' interests in the activity; and d) the existence of potential conflict with regulation by other states. Id. The State Department acknowledged that its balancing methodology was derived from decisions in U.S. courts such as Timberlane Lumber Co. v. Bank of America N.T. \& S.A., 549 F.2d 597 (9th Cir. 1976) and Mannington Mills, Inc. v. Congoleum Corp., 595 F.2d 1287 (3rd Cir. 1979). Id. This balancing approach is also reflected in Section 403 of the Restatement (THIRD) OF ForEign Relations LAW of the UNited States (Draft No. 7, Jan. 18, 1985). 
Although the United States admitted that the balancing approach could not resolve all intra-alliance controversies, the economic needs of some alliance members were seen as subsidiary to the overriding concern for collective security.

The U.S. claimed that its extension of jurisdiction to foreign country activities was part of a pattern of practice long accepted in international relations. ${ }^{99}$ This is not to say that the U.S. was oblivious to the problems created between the U.S. and its European allies by extensions of U.S. jurisdiction, particularly in the antitrust area. ${ }^{100}$ The administration maintained, however, that its assertion of jurisdiction over a foreign subsidiary of a U.S. corporation or the licensee of U.S. technology fit a consistent historical pattern of practice where substantial U.S. interests were involved. 101

U.S. legal arguments thus focussed on the reasonable foreseeability of the extension of sanctions. The U.S. view was that its allies' obligations to the Alliance included a commitment to view their economic cooperation with the Soviets in terms of security goals and politico-military power. Moreover, the contractual stipulations should have put the Europeans on notice that sanctions could be imposed. Finally, the extension of sanctions to European subsidiaries of U.S. firms should have been expected, given the historical pattern of U.S. extensions of jurisdiction.

\section{B. European Claims}

Although the dispute among the allies began with the announcement of sanctions on December 30,1981, from the European point of view, the real conflict did not begin until the extension of sanctions to American subsidiaries and license-holders in Europe on June 18, 1982. These restrictions were crucial because they directly affected European companies and threatened to cut off a vital conduit for equipment needed for the pipeline.

European legal arguments focused on two claims. ${ }^{102}$ First, the allies asserted that the U.S. regulations, as amended June 22, 1982, ${ }^{103}$ con48.

99. Dam, Extraterritoriality and Conflicts of Jurisdiction, DEP'T ST. BuLL., June 1983, at

100. Id. at 48,49 .

101. Id. at 50 .

102. For a full elaboration of the European legal arguments, see European Communities: Comments on the U.S. Regulations Concerning Trade with U.S.S.R., 21 I.L.M. 589, 891-904 (1982).

103. On June 22, 1982, the Department of Commerce, at the direction of President Reagan and pursuant to If 6 of the 1979 Export Administration Act, supra note 29, amended $\S \S 376.12,379.8$, and 385.2 of the Export Administration Regulations. 15 C.F.R. $\$ \S 376.12$, 379.8, 385.2. These amendments expanded coverage of existing United States controls on the 
tained sweeping extensions of U.S. jurisdiction violative of international law. Second, they claimed that the new regulations, and the way in which they affected contracts in the course of performance, ran counter to the guidelines of the 1979 Export Administration Act ${ }^{104}$ and to "principles of U.S. public law."105

The first claim, concerning extension of U.S. jurisdiction, was analyzed by the Europeans under four different jurisdictional principles of international law - the territoriality principle, the protective principle, the nationality principle, and the effects principle. Analysis of each principle led the Europeans to conclude that U.S. measures were unacceptable under international law. The territoriality principle ${ }^{106}$ supports the right of each state, as part of the state system created by the U.N. Charter, freely to organize and develop its social and economic system. The Europeans argued that U.S. measures infringed upon this principle by attempting to regulate the activities of European companies that were not within the territorial jurisdiction of the United States. Anticipating American arguments about their security obligations under the Atlantic Alliance, the Europeans noted that the U.S. might have grounded its claims on the "protective principle" of jurisdiction. This principle allows a state jurisdiction over acts committed outside its territory that threaten its security. ${ }^{107}$ Whether or not this principle might have been available to the United States, the Europeans pointed out that it "was not invoked by the U.S. government, since the regulations were based on $\S 6$ (foreign policy controls) and not on $\S 5$ (national security controls) of the 1979

export and reexport of goods and technical data relating to oil and gas exploration. The Europeans understood the regulations, as amended, to provide that: a) persons (individuals, corporations and partnerships) within a third country could not reexport machinery of U.S. origin without the permission of the U.S. government if it was for the exploration and production of oil and natural gas; b) persons subject to United States jurisdiction were required to get prior written authorization by the Office of Export Administration for the export or reexport to the Soviet Union of non-United States goods and technical data related to oil and gas exploration; and c) no person in the United States or in a foreign country could export or reexport to the Soviet Union foreign products directly derived from United States technical data relating to machinery utilized for the exploration and production of oil or natural gas. I.L.M., supra note 102, at 891-892 (1982) (summary of regulations).

104. See supra note 29.

105. I.L.M., supra note 102, at 891.

106. Restatement (SECOND) OF Foreign Relations LAW $\$ 17$ (1965) [hereinafter cited as Restatement (SeCond)]. See also M. McDougal \& W. Reisman, InternaTIONAL LAW IN CONTEMPORARY PERSPECTIVE 1295 (1981). The territoriality principle has been interpreted to mean that a state should restrict its rulemaking to persons and goods within its territory. It also means that an organization such as the European Community should restrict applicability of its rules to the territory to which the treaty creating it applies. I.L.M., supra note 102, at 893 (1982).

107. Restatement (SECOND), supra note 106, at § 30.33. See also M. MCDougal \& W. ReISMAN, supra note 106, at 1319. 


\section{Export Administration Act."108}

The nationality principle, authorizing prescriptions of rules for nationals wherever they are, ${ }^{109}$ was also rejected by the Europeans as a basis for the extension of U.S. jurisdiction. The Europeans objected to the notion that the U.S. could impose its corporate nationality controls on European companies given that "the great majority were incorporated in European states." 110 Further, they added that there were no rules for determining the nationality of goods and technology under international law, ${ }^{111}$ and that judicial decisions indicated that U.S. jurisdiction did not follow goods of U.S. origin once they had been discharged in the territory of another country. ${ }^{112}$ Finally, the Europeans argued that the "effects principle" 113 was not applicable because exports from European members were deemed to have no "direct, foreseeable, and substantial" effect on U.S. trade.

The second European claim was that the U.S. controls did not satisfy the criteria laid down in the 1979 Export Administration Act. ${ }^{114}$ The Europeans argued that there was little probability that controls would achieve foreign policy purposes. ${ }^{115}$ They urged that there was no reason to assume that the Soviets would be unable to develop their own technology, albeit at a greater cost, in order to complete the project and make the U.S. pipeline policy ineffective. The Europeans also argued that the probable reaction of other countries to the imposition or expansion of export controls had received insufficient consideration as required by the Act. ${ }^{116}$ Finally, the Europeans claimed that the export controls would cast doubt on the United States as a reliable supplier, both in sales of equipment and in technology licensing arrangements. ${ }^{117}$

108. See supra note 29.

109. Restatement (Second), supra note 106, at § 30. See also M. McDougal \& W. REISMAN, supra note 106, at 1370-72.

110. I.L.M., supra note 102 , at 894 .

111. Id.

112. Id.

113. RESTATEMENT (SECOND), supra note 106 at $\S 18$. The Europeans referred to the "effects doctrine," which grants jurisdiction over conduct outside the territory that causes direct, foreseeable, and substantial effects within the territory. I.L.M., supra note 106, at 896 (1982) (citing RESTATEMENT (SECOND), supra note 106).

114. Congress attempted to circumscribe Presidential power by requiring the application of specified criteria when imposing, expanding, or extending export controls for foreign policy reasons. For an elaboration of these criteria, see 50 U.S.C. $\S 2405(b)$ (1982).

115. I.L.M., supra note 102, at 901-02.

116. Id. at 902 .

117. Id. 


\section{Outcome}

The ban on the sale of pipeline equipment to the Soviet Union by U.S. firms, foreign subsidiaries of U.S. firms and foreign companies manufacturing under U.S. licenses was lifted on November 13, 1982. President Reagan, in a radio address to the nation, announced that the United States and its allies had come to an informal agreement on trade policy with the Soviet Union. ${ }^{118}$ The President claimed that this "understanding" with the European allies would be more effective than the sanctions, ${ }^{119}$ and that the latter were now obsolete. The President highlighted three aspects of this agreement that established a "policy in the economic area to complement our policies in the security area." 120 First, no new contracts for the purchase of Soviet natural gas would be signed during the course of an alliance study of alternative Western sources of energy. Second, the United States and its allies would strengthen controls on the transfer of strategic items to the Soviet Union. Third, procedures would be established for monitoring financial relations with the Soviet Union which would be consistent with alliance export credit policies. 121

In order to put this outcome in the proper focus so that it might be appraised for its impact on community expectations, ${ }^{122}$ two points must be made. First, as mentioned above, the natural gas contracts that the European allies signed with the Soviet Union were all long-term agreements: West Germany - twenty-five years; France-twenty-five years; Italy-twenty years. As a result, the first aspect of this "informal agreement" had no operative significance since the allies' present needs would be satisfied by existing contracts. Second, this "informal agreement" contained no mention of future limitations on sales contracts of pipeline equipment. Thus, while U.S. policy changed with the lifting of the sanctions, it is important to note that European behavior remained basically unaltered.

\section{International Appraisal}

Although the political rhetoric on each side of the Atlantic still reflected the differing perspectives of the parties, the arguments used by

118. East-West Trade Relations and the Soviet Pipeline Sanctions, DEP'T ST. BuLI., Jan. 1983, at 28. (Text of President Reagan's address to the nation, Nov. 13, 1982) [hereinafter cited as Presidential Address].

119. Id.

120. Id.

121. Id.

122. McDougal, Lasswell \& Reisman, supra note 3, at 285. 
each in appraisal of the outcome indicated a recognition that politicomilitary responsibilities of alliance members could not automatically be extended to the peacetime trade of commercial goods.

\section{A. U.S. Appraisal}

U.S. appraisal of the pipeline incident was marked both by reluctance to admit the rejection of its policies by its allies, and by uncertainty over how to address European assertions of independence in the choice of trading partners. The Reagan Administration originally couched its decision to lift the pipeline sanctions in language that gave the impression of a united alliance in agreement over a future course of action that would be even more effective against the Soviet Union. ${ }^{123}$ Yet it is apparent that this settlement was less a shift from one agreed-upon policy to another than a realization by the United States that it could not effectively translate alliance responsibilities in the politico-military issue area into the economic issue area. As President Reagan admitted in lifting the sanctions: "It's no secret that our allies don't agree with [the sanctions policy]." 124 What the "agreement" demonstrated was that in the future such matters would be determined, not through unilateral action on the part of the alliance leader, but through allied consensus. ${ }^{125}$

The reappraisal by U.S. elites that was stimulated by the incident may be illustrated by the difficulties encountered in attempting to revise the 1979 Export Administration Act and to formulate a coherent export control policy. The administration, the Senate and the House of Representatives brought divergent approaches to the task. ${ }^{126}$

In April 1983, the Reagan Administration submitted a bill to Congress that indicated a greater respect for its allies' economic independence than had been the case at the outset of the incident. ${ }^{127}$ The bill stated that it would be U.S. policy to minimize the impact of export controls on pre-

123. President Reagan, in his radio address announcing the end of the pipeline sanctions, asserted: "I believe this new agreement is a victory for all the allies. It puts in place a much needed policy in the economic area to complement our policies in the security area . . . an agreement with our allies which provides for stronger and more effective measures." Presidential Address, supra note 118.

124. Id.

125. Dam, supra note 99 , at 51.

126. As of June, 1985 Congress has yet to reenact an updated version of the Export Administration Act. Compare S. 2342, 98th Cong., 2d. Sess. $\$ 2$ and H.R. Rep. No. 257, Part I, 98th Cong., Ist Sess. (1983). On June 27, 1985, the Congress passed and sent to President Reagan a bill extending the current version of the Export Administration Act until Sept. 30, 1989. N.Y. Times, June 28, 1985, at D4, col. 4. Extension of the status quo reflects Congressional uncertainty over how to proceed and at least a temporary acceptance of the proposed norm.

127. Dam, supra note 99 , at 51 . 
existing contracts and business activities in allied countries when these controls are imposed for foreign policy reasons. The administration bill also explicitly recognized the sanctity of contracts as a limitation which would insulate many contracts from foreign policy export controls. Specifically, an "overriding national interest" exception protected existing sales contracts requiring delivery within 270 days of the imposition of restrictions. Although the bill strengthened the enforcement of national security controls, the concessions on foreign policy controls indicated that elite opinion in the executive branch had shifted. Although the Congressional position is still in a state of flux, the administration's position indicated an awareness that consultation with the allies and increased information flow regarding alliance objectives, rather than the use of political power by the United States, has become the norm of behavior on trade issues within the Atlantic Alliance. ${ }^{128}$

\section{B. European Appraisal}

European reaction to the lifting of the pipeline sanctions was uniform. The incident consolidated European expectations of what their alliance obligations were in peacetime concerning trade issues. Such consolidation capped a process of norm formation that had accelerated during the period of detente.

In the Federal Republic of Germany, the lifting of the sanctions was interpreted by the Frankfurter Allgemeine Zeitung as the end of "intervention into the sovereignty of foreign countries." 129 The value of EastWest trade was reaffirmed by West German elites as a political instrument and a stabilizing factor in East-West relations. ${ }^{130}$ Further, the normative implications of the lifting of sanctions were not missed. As Die Welt commented, "Some good, however, has come out of this struggle in the Western alliance over the past months because there is now a clearer definition of a common and coordinated policy regarding trade with the East."131 This view, that the incident had clarified and reaffirmed community policy on the allocation of competence to prescribe and apply norms of economic behavior during peacetime, was also evident among the other European allies. The French Foreign Trade Minister, Michel Jobert, echoed this theme: "We are urging the United States to regard us as partners, to see that we are not part of a system controlled by its

128. Robinson, supra note 97, at 37-38.

129. Press Discusses Lifting of U.S. Pipeline Embargo, Foreign Broadcast Information Service [hereinafter cited as FBIS] (W. Eur.), Nov. 16, 1982, at J1.

130. Genscher on Trade After Shultz USSR Meeting, FBIS (W. Eur.), Nov. 16, 1982, at 53.

131. Press Discusses Lifting of US Pipeline Embargo, supra note 129, at J1. 
initiative."132 Moreover, French reaction to the lifting of the sanctions highlighted substantive differences within the Alliance on the trade issue. France simply did not share the security objectives of U.S. embargo policies, ${ }^{133}$ refusing even to be party to the "informal agreement" among the allies through which the Reagan Administration sought to save face in lifting the sanctions. ${ }^{134}$

Great Britain also refused to take part in the "informal agreement." Foreign Secretary Pym emphasized that the sanctions policy and the decision to end it were unilateral actions of the United States. ${ }^{135}$ Britain, however, was more conciliatory than any other European ally towards the United States on the issue of East-West security principles. ${ }^{136}$ The British acknowledged that the alliance could not trade in ways that gave the Soviets strategic or military advantages. ${ }^{137}$ However, the British acknowledgement of shared security interests did not extend to trade in commercial goods with less direct military applications.

At the other end of the world, the Japanese were also applauding the lifting of the pipeline sanctions, since this would enable them to resume fully their oil and gas projects with the Soviets. ${ }^{138}$ The Japanese had protested strongly 139 the imposition of the sanctions, asserting that "the United States need[ed] to listen to the voices of its Western allies." 140 In addition, elite reaction in Japan welcomed the lifting of the pipeline sanctions because, like the West Europeans, the Japanese wanted orders to alleviate a recession in the steel sector. ${ }^{141}$

The allies generally maintained a uniform position regarding both the sanctions policy and its withdrawal. ${ }^{142}$ They wanted no part of either. So far as the allies were concerned, the United States was expecting too much of the alliance in extending obligations for Western security broadly to the economic area. ${ }^{143}$ The ability to trade with minimum in-

132. Jobert Comments on Lifting of Sanctions, FBIS (W. Eur.), Nov. 18, 1982, at K2.

133. Le Monde Views Decision, FBIS (W. Eur.), Nov. 17, 1982, at K2.

134. Leaders Comment on Lifting of U.S. Sactions, FBIS (W. Eur.), Nov. 17, 1982, at K1.

135. Pym on East Bloc Trade After Sanctions Lifted, FBIS (W. Eur.), Nov. 15, 1982, at Q1.

136. Id. at $\mathrm{Q} 2$.

137. Id.

138. MITI Lauds Lifting of U.S. Pipeline Sanctions, FBIS (Japan), Nov. 16, 1982, at C5.

139. Abe Confirms Protest, FBIS (Japan), July 20, 1982, at C1.

140. Trade Minister Criticizes U.S. Economic Policy, FBIS (Japan), July 8, 1982, at C1.

141. USSR Seeking Japanese Credits for Pipeline Equipment, FBIS (Japan), Oct. 19, 1982, at $\mathrm{C}$.

142. Italy maintained a low profile during the entire incident. However, Prime Minister Giovanni Spadolini, in appraising the lifting of the sanctions, emphasized the consistency of Italian policy during this incident in reserving its right to freedom of action in trade contracts. See Spandolini Interviewed on Economy, U.S. Embargo, FBIS (W. Eur.), Nov. 17, 1982, at L5.

143. Soames, America and Europe: Can This Partnership Be Saved? 20 ATLANTIC ComMUNITY 331, 332 (1982). 
terference was considered by Europeans to be an aspect of political independence that the United States must respect. ${ }^{144}$

\section{Writer's Appraisal}

The informal agreement reached on November 13, 1982 by the United States and its European allies did nothing to impede completion of the pipeline project. The pipeline was duly completed and is in operation. ${ }^{145}$ As noted above, the agreement has also had little effect on the trade policies of the allies. The ban on new natural gas contracts did not affect the long-term arrangements previously concluded by the Europeans and the Soviet Union. No further restrictions on sales contracts were contemplated by the agreement, and its recommendations for stronger controls on strategic items have not been implemented. Yet, despite the failure of the agreement to alter the behavior of the Europeans, no new crisis over East-West industrial technology sales has occurred within the alliance. ${ }^{146}$ Rather, the agreement seems to represent a recognition by all parties of an emerging norm that the scope of politico-military alliances does not automatically extend to the peacetime trade of commercial goods. ${ }^{147}$ The outcome of the pipeline incident suggests that delegation of duties

144. Id. at 333. The utility of the sanctions was questioned even by Americans doing business in Europe. Tittman, Extraterritorial Application of United States Export Control Laws to Foreign Subsidiaries of United States Corporations: An American Lawyer's View from Europe, 16 INT'L LAw. 730 (1982). Soviet commentators naturally also stressed as unnecessary and futile the U.S. attempt to restrict its allies' commercial transactions. See Gorsky, EEC-USA: The Transatlantic Duel, INT'L AFr. (Moscow), Oct. 1982, at 24.

145. See Chronology 1984, supra note 1.

146. Hoffman, Western Europe: Wait and Worry, 63 FoREIGN AFF. 632 (1985).

147. The applicability of this norm to other alliances will vary according to the relative dominance of the state apparatus (as a concept distinct from society) in attempting to implement alliance policy. A key factor in establishing this dominance is the degree to which societal pressures condition state policies. See Katzenstein, supra note 6, at 16-18. As a predictive matter, it is likely that when private interests are influential in economic matters, it will be more difficult for the state to impose alliance policies that run counter to those interests. There is also reason to believe, however, that the norm proposing freedom of peacetime commercial transactions would be supported even within alliances in which the power of the dominant state to enforce a strategy of trade denial is relatively unrestrained by internal pressures. See Bunce, The Empire Strikes Back: The Transformation of the Eastern Bloc from a Soviet Asset to a Soviet Liability, 39 INT'L ORG. 1 (1985). The rapid expansion of East-West trade during the 1970s brought "a nine-fold increase from 1970 to 1981 of Western exports to the [Soviet] bloc, and an eight-fold increase in the same period of Western imports from the Soviet bloc." $I d$. at 36. This expansion resulted in Eastern Europe becoming more dependent on both the West and the Soviet Union for markets and capital. Id. at 3. Bunce argues that the pressures East-West trade placed on the command economies of Eastern Europe, the need for Western banks to recycle petrodollars in Eastern Europe in the 1970s, and the global recessions of 197374 and 1979-82 all served to limit, rather than expand, Soviet power over the Eastern alliance. Id. at 44 . This thesis suggests that it would be difficult for the Soviet Union to mobilize its alliance partners to deny economic power to the West. In fact, because of diminishing returns from its empire, the Soviet Union may be quite content to limit its control over state sovereignty to political and military affairs. 
within the alliance, especially in regard to the wealth process, is to be determined by consultation, not imposition. Alliance duties are to be carefully defined so as to respect the autonomy of each state. While the United States might invoke alliance responsibilities in the name of collective security, or alternatively, issue unilateral export regulations on grounds of its own national security, mere assertions of foreign policy objectives will not justify extensions of U.S. sanctions to its allies.

The norm embodied in the informal agreement represents a crystallization of expectations which developed over time in response to repeated attempts by the United States to implement trade restrictions. The Europeans have acted, and will continue to act in accordance with these expectations. For a period following the pipeline incident, the United States also had begun to act in conformity with these expectations, with the result that economic autonomy in commercial transactions was accorded much more weight in the crafting of export control policy. However, on May 1, 1985, the Reagan Administration tried once again to get its allies to cooperate in a trade embargo to counter a "security" threat posed by Nicaragua. ${ }^{148}$ Although this attempt to extend politico-military responsibilities into the economic issue area seems to have been unsuccessful, ${ }^{149}$ the Nicaragua "incident" offers an opportunity to test the viability of the norm proposed here.

The new norm manifests a preference by most members of the Atlantic Alliance that each state be free to engage in peacetime commercial transactions, even at the risk of transferring power through the wealth process to an adversarial alliance. The ability of these members to prevail suggests, in a larger sense, that spheres of influence promoted by the framework of collective security have their limits. Collective security arrangements exist to safeguard the public order goal of national autonomy. ${ }^{150}$ These collective arrangements are thus a means of achieving a public order goal and not an end in themselves. The clear lesson of the pipeline incident is that alliance members will strenuously take issue with policies that they perceive as a threat to the very goals that the alliance exists to promote.

148. Weinraub, Reagan Declaring 'Threat,' Forbids Nicaraguan Trade and Cuts Air and Sea Links, N.Y. Times, May 2, 1982, at A1, col. 6.

149. Oakes, Reagan's Brezhnev Doctrine, N.Y. Times, May 20, 1985, at A19, col. 2.

150. See supra note 7 and accompanying text. 